University of South Florida

DIGITAL COMMONS

Digital Commons @ University of

@ UNIVERSITY OF SOUTH FLORIDA

South Florida

$11-1-2002$

\title{
A Multiproxy Approach to Reconstructing Sea Surface Conditions Using Coral Skeleton Geochemistry
}

Terrence M. Quinn

University of South Florida, quinn@marine.usf.edu

Daniel E. Sampson

University of California, San Francisco

Follow this and additional works at: https://digitalcommons.usf.edu/msc_facpub

Part of the Marine Biology Commons

\section{Scholar Commons Citation}

Quinn, Terrence M. and Sampson, Daniel E., "A Multiproxy Approach to Reconstructing Sea Surface Conditions Using Coral Skeleton Geochemistry" (2002). Marine Science Faculty Publications. 111.

https://digitalcommons.usf.edu/msc_facpub/111

This Article is brought to you for free and open access by the College of Marine Science at Digital Commons @ University of South Florida. It has been accepted for inclusion in Marine Science Faculty Publications by an authorized administrator of Digital Commons @ University of South Florida. For more information, please contact digitalcommons@usf.edu. 


\title{
A multiproxy approach to reconstructing sea surface conditions using coral skeleton geochemistry
}

\author{
Terrence M. Quinn \\ College of Marine Science, University of South Florida, St. Petersburg, Florida, USA
}

\author{
Daniel E. Sampson \\ Department of Earth Sciences, University of California at Santa Cruz, Santa Cruz, California, USA
}

Received 2 April 2000; revised 11 April 2002; accepted 8 May 2002; published 30 October 2002.

[1] We use elemental ratio $(\mathrm{Mg} / \mathrm{Ca}, \mathrm{Sr} / \mathrm{Ca}, \mathrm{U} / \mathrm{Ca}$ and $\mathrm{Ba} / \mathrm{Ca})$ and oxygen isotope data from a Porites lutea coral head collected from offshore Amédée Island, New Caledonia $\left(22^{\circ} 29^{\prime} \mathrm{S}, 166^{\circ} 28^{\prime} \mathrm{E}\right)$ to assess the degree to which changes in these geochemical variables reflect variations in sea surface conditions. We have assessed the robustness of each geochemical proxy by comparing 25 years $(1992-1968)$ of monthly geochemical variations with a local record of sea surface temperature (SST) and with the appropriate $1^{\circ}$ by $1^{\circ}$ grid box from a global gridded SST data set. We conclude from our comparison that the most consistent proxies of monthly SST variations at this site are $\delta^{18} \mathrm{O}\left(\mathrm{r}^{2}=-0.84 ; \mathrm{p}=<.0001\right)$ and $\mathrm{Sr} / \mathrm{Ca}\left(\mathrm{r}^{2}=-0.84 ; \mathrm{p}=<.0001\right)$. The fidelity of the coral-based $\mathrm{Sr} / \mathrm{Ca}-\mathrm{SST}$ proxy was assessed via calibration-verification exercises at New Caledonia and Rarotonga. The "paleoclimate" accuracy of the coral Sr/Ca-SST technique is judged to be robust, and the precision of the technique is estimated to be $\sim 0.3^{\circ} \pm 0.5(2 \sigma)$ based on the calibration-verification exercise. In contrast, monthly variations in $\mathrm{Mg} / \mathrm{Ca}$ and $\mathrm{U} / \mathrm{Ca}$ ratios are only moderately correlated with monthly SST variations $\left(\mathrm{r}^{2}=0.55 ; \mathrm{p}=<.0001\right.$ for $\mathrm{Mg} / \mathrm{Ca}$ and $\left.\mathrm{r}^{2}=0.47 ; \mathrm{p}=<.0001\right)$. The strength of the correlation between $\mathrm{SST}$ and $\mathrm{Mg} / \mathrm{Ca}$ and $\mathrm{U} / \mathrm{Ca}$ varies as a function of time, suggesting that variations in these ratios are not a simple function of SST variations. This variability in goodness of fit between U/Ca-SST and $\mathrm{Mg} / \mathrm{Ca}-\mathrm{SST}$ may ultimately limit the use of these ratios as coral paleothermometers. Averaging or stacking individual proxy SST records $(\mathrm{Sr} / \mathrm{Ca}, \mathrm{Mg} / \mathrm{Ca}$ and $\mathrm{U} / \mathrm{Ca})$ to generate a composite proxy SST record does not necessarily improve the proxy record if the signal-to-noise ratio in each proxy is highly variable. For example, stacking of $\mathrm{Sr} / \mathrm{Ca}-\mathrm{Mg} / \mathrm{Ca}-$ $\mathrm{U} / \mathrm{Ca}$ records at New Caledonia produces a proxy SST time series that has greater standard error than the individual $\mathrm{Sr} / \mathrm{Ca}$-SST time series (cf. ordinary least squares standard error of $1.16^{\circ} \mathrm{C}$ versus $0.86^{\circ} \mathrm{C}$ ). $\mathrm{Ba} / \mathrm{Ca}$ variations have little correlation with $\mathrm{SST}, \mathrm{Sr} / \mathrm{Ca}, \mathrm{Mg} / \mathrm{Ca}$, or $\mathrm{U} / \mathrm{Ca}$ variations at New Caledonia. In conclusion, variations in oxygen isotopic composition of seawater, calculated by removing the $\mathrm{Sr} / \mathrm{Ca}$-based temperature component of the $\delta^{18} \mathrm{O}$ signal, agree reasonably well with observed variations in sea surface salinity, especially at the interannual timescale. INDEX TERMS: 4825 Oceanography: Biological and Chemical: Geochemistry; 1030 Geochemistry: Geochemical cycles (0330); 1050 Geochemistry: Marine geochemistry (4835, 4850); KEYWORDS: coral, climate, stable isotopes, elemental ratios

Citation: Quinn, T., and D. E. Sampson, A multiproxy approach to reconstructing sea surface conditions using coral skeleton geochemistry, Paleoceanography, 17(4), 1062, doi:10.1029/2000PA000528, 2002.

\section{Introduction}

[2] The tropical ocean-atmosphere system plays a significant role in climate change on a variety of timescales including human ones. Variations in sea surface temperature (SST) and sea surface salinity (SSS) are integral to the dynamics of the tropical ocean-atmosphere system. These two variables are linked via the positive, strongly nonlinear relation between SST and moisture advection in the tropics. Reconstruction of changes in the tropical ocean-atmosphere system in the period prior to the instrumental record requires the use of climate proxies, such as corals, tree

Copyright 2002 by the American Geophysical Union. 0883-8305/02/2000PA000528 rings, and ice cores. Scleractinian corals are well suited for high-resolution climate change studies because many grow rapidly ( $>1 \mathrm{~cm} /$ year) and are long-lived (many centuries), their skeletons contain couplets of high- and low-density bands, representing $\sim 1$ year of growth, and their aragonite skeletons are amenable to geochemical study.

[3] Oxygen isotopic analysis of coral skeletal material is a traditional method with which to calculate SSTs of the tropical oceans. Such analyses are attractive from the standpoint that the technique and instrumentation needed to make the determinations is very mature and most modern stable isotope laboratories have automated carbonate devices, which make stable isotopic determinations at a rate of $\sim 20$ to $30 \mathrm{~min}$ per sample. However, the prospect of generating several multicentury coral records remains daunting because 
Table 1. Select Methods and Analytical Precision for Element/Ca Ratio Determinations in Biogenic Carbonates

\begin{tabular}{|c|c|c|c|c|}
\hline \multirow[b]{2}{*}{ Method } & \multirow[b]{2}{*}{ Sample Type } & \multicolumn{3}{|c|}{ Analytical Precision, $\%$ RSD, $1 \sigma$} \\
\hline & & $\mathrm{Sr} / \mathrm{Ca}$ & $\mathrm{Mg} / \mathrm{Ca}$ & $\mathrm{U} / \mathrm{Ca}$ \\
\hline TIMS & coral & $0.05-0.1$ & no data & 0.2 \\
\hline ICP-MS & coral & 0.25 & no data & 0.5 \\
\hline ICP-AES & coral & $0.1-0.2$ & $0.3-0.5$ & no data \\
\hline SF-ICP-MS ${ }^{1}$ & foram & 0.45 & 0.45 & 1.4 \\
\hline SF-ICP-MS ${ }^{2}$ & coral & 0.33 & 0.33 & 0.6 \\
\hline Ion microprobe & coral & 0.2 & 0.6 & no data \\
\hline LA-ICP-MS & coral & 1 & 1 & 2.5 \\
\hline Method & \multicolumn{2}{|c|}{ Description } & \multicolumn{2}{|c|}{ Source } \\
\hline ID-TIMS & \multirow{6}{*}{\multicolumn{2}{|c|}{$\begin{array}{l}\text { isotope dilution, thermal ionization mass spectrometry } \\
\text { inductively coupled plasma mass spectrometry } \\
\text { inductively coupled plasma atomic emission spectrometry } \\
\text { sector field, inductively coupled plasma mass spectrometry } \\
\text { sector field, inductively coupled plasma mass spectrometry }\end{array}$}} & \multicolumn{2}{|c|}{ [Beck et al., 1992; Min et al., 1995] } \\
\hline ICP-MS & & & \multicolumn{2}{|c|}{ [LeCornec and Corrège, 1997] } \\
\hline ICP-AES & & & \multicolumn{2}{|c|}{ [Schrag, 1999; de Villiers et al., 2002] } \\
\hline${ }^{1}$ SF-ICP-MS & & & \multicolumn{2}{|c|}{ [Rosenthal et al., 1999] } \\
\hline${ }^{2}$ SF-ICP-MS & & & \multicolumn{2}{|l|}{ [this study] } \\
\hline Ion microprobe & & & \multicolumn{2}{|c|}{$\begin{array}{l}\text { [Allison and Tudhope, 1992; Allison, 1996a, 1996b; } \\
\text { Hart and Cohen, 1996; Cohen et al., 2001, 2002] }\end{array}$} \\
\hline LA-ICP-MS & \multicolumn{2}{|c|}{ laser ablation, inductively coupled plasma mass spectrometry } & \multicolumn{2}{|c|}{ [Sinclair et al., 1998; Fallon et al., 1999] } \\
\hline
\end{tabular}

just a single 400 year, monthly resolved, coral stable isotope time series would require $\sim 50 \%$ of the yearly capacity of a typical stable isotope facility. The generation of multicentury coral $\delta^{18} \mathrm{O}$-based records of SST or SSS variations are further complicated because both thermal and hydrologic factors influence the oxygen isotopic composition of coralline aragonite. In regions of the world's oceans where one factor dominates the other (e.g., $\Delta \mathrm{SST} \gg \Delta \mathrm{SSS}$ ) it may be possible to attribute coral $\delta^{18} \mathrm{O}$ variations solely to SST or SSS. However, multicentury records of SST or SSS variations reconstructed from coral $\delta^{18} \mathrm{O}$ implicitly assume that the coral $\delta^{18} \mathrm{O}$-SST-SSS relationship has remained stationary throughout the period of reconstruction. Crowley et al. [1999] demonstrated that the assumption of stationarity does not hold at several sites where coral $\delta^{18} \mathrm{O}$-based SST records have been reconstructed.

[4] Element/Ca ratio analysis of coral skeletal material has also been used to calculate SSTs of the tropical oceans. A well-established relationship exists between SST and Sr/ Ca [e.g., Weber, 1973; Smith et al., 1979; Beck et al., 1992; Shen et al., 1996; Alibert and McCulloch, 1997; Schrag, 1999; Gagan et al., 2000]; SST and Mg/Ca [e.g., Oomori et al., 1983; Mitsuguchi et al., 1996]; and SST and U/Ca [Min et al., 1995; Shen and Dunbar, 1995]. The sensitivity of Sr/ $\mathrm{Ca}$ is $\sim 0.7 \%$ per $1{ }^{\circ} \mathrm{C}$ change in SST [Beck et al., 1992], whereas the sensitivity for $\mathrm{Mg} / \mathrm{Ca}$ it is $3.5 \%$ per $1{ }^{\circ} \mathrm{C}$ change in SST [Mitsuguchi et al., 1996], and for U/Ca the sensitivity is $\sim 4.0 \%$ per $1{ }^{\circ} \mathrm{C}$ change in SST [Shen and Dunbar, 1995; Min et al., 1995]. In theory, a multiproxy approach that combines elemental ratios and oxygen isotope data from the same sample should permit the isolation and identification of the specific thermal and hydrologic variations at a coral site [McCulloch et al., 1994; Gagan et al., 1998]. The various analytical methods and instruments that have been used to determine element/Ca ratios in biogenic carbonates, especially coral skeletons, are summarized in Table 1. The generation of multicentury, monthly resolved records of elemental variations in coral skeletons is entirely feasible because of the combination of high analytical precision and rapid sample throughput (e.g., 2 to $3 \mathrm{~min}$ per sample for a suite of elements) for most of the analytical methods listed in Table 1. Linsley et al. [2000] recently published the first, multicentury record of coral Sr/Ca-SST variations at Rarotonga, nicely demonstrating the efficiency with which such records of elemental ratio variations in coral skeletons can be produced.

[5] Theoretically, element/Ca-SST relationships determined from modern corals can be used to reconstruct past changes in tropical SST using fossil corals; if the fossil corals can be demonstrated to be pristine and not diagenetically altered. Even when fossil corals can be demonstrated to be pristine, "coral paleothermometry" will be complicated because of the potential secular variation in seawater element/Ca ratios. For example, there is now strong evidence for secular variations in seawater $\mathrm{Sr} / \mathrm{Ca}$, which will affect the accuracy of coral $\mathrm{Sr} / \mathrm{Ca}$ on glacial to interglacial timescales [Stoll and Schrag, 1998; Martin et al., 1999].

[6] In this paper we exploit the analytical capabilities of a sector field inductively coupled plasma mass spectrometer (SF-ICP-MS; i.e., abundant sensitivity, high precision, and great linearity over a wide mass range) to rapidly and precisely generate multielement, multiproxy paleoclimate records from the skeleton of an aragonite coral from New Caledonia. We combine elemental ratio data with oxygen isotopic data to more completely address the ability of each geochemical proxy to track changes in SST and SSS. The New Caledonia location is particularly attractive for calibrating a geochemical proxy with in situ environmental data because historical measurements of daily SST and SSS are available from ORSTOM de Noumea (now Institut de Recherche pour le Developpement, IRD) for offshore of Amédée Island for the past 25 years. In addition, this local SST time series is highly correlated with SST data extracted from the appropriate grid square $\left(1^{\circ}\right.$ latitude by $1^{\circ}$ longitude) of a global SST data set (e.g., GISST2.3b; [Parker et al., 1995], as documented by Quinn et al. [1998]).

\section{Methods}

\subsection{Coral Sampling}

[7] A large coral head (Porites lutea) was drilled in $3 \mathrm{~m}$ of water offshore of the lighthouse on Amédée Island, New 
Caledonia in June 1992, and has been extensively described elsewhere [Quinn et al., 1996, 1998]. Physical sampling of the coral was performed using a computer-aided triaxial sampler after the core was slabbed to a thickness of $5 \mathrm{~mm}$. Drill bit diameter was $1 \mathrm{~mm}$ and sample depth was $0.5 \mathrm{~mm}$. Samples of coralline aragonite powder averaged $1 \mathrm{mg}$ in weight. We resampled the top portion of this coral head using the same $1.03 \mathrm{~mm} / \mathrm{sample}$ ( $\sim$ monthly) resolution that was used in the original stable isotope study of this coral [Quinn et al., 1996]. Two parallel sampling paths (paths A and B) were sampled to maintain equivalent positions with respect to lobate morphology of the coral skeleton growth bands. Path A started at the top of the coral head and ended at a depth of $135.96 \mathrm{~mm}$ for a total of 132 samples. Path B started at $120.51 \mathrm{~mm}$ and ended at $304.88 \mathrm{~mm}$ for a total of 180 samples. The end of path A and the beginning of path B overlapped for $15.45 \mathrm{~mm}$ and are separated by $10 \mathrm{~cm}$. Sample depth is converted to time by matching the seasonal cycle of SST and $\delta^{18} \mathrm{O}$, a standard technique in coral-based climate studies. The resultant time series is 25 years long, extending from 1992 to 1968 .

\subsection{Elemental Ratio Analysis}

[8] The analytical method used in this study was developed on a SF-ICP-MS (Finnigan MAT Element) at the University of California at Santa Cruz [Quinn and Sampson, 1998]. Our method builds on the internal-standardization and isotope-dilution techniques previously developed for coral paleoclimate work on the more traditional inductively coupled plasma, quadrupole mass spectrometers [Lea et al., 1989; Shen and Dunbar, 1995; Lea and Martin, 1996; LeCornec and Corrège, 1997]. Our method is broadly similar to the technique developed by Rosenthal et al. [1999]. We use Sc for ${ }^{24} \mathrm{Mg}$ and ${ }^{43} \mathrm{Ca}$ analysis, Y for ${ }^{86} \mathrm{Sr}$ analysis, Ce for ${ }^{137} \mathrm{Ba}$ analysis, and ${ }^{209} \mathrm{Bi}$ for ${ }^{238} \mathrm{U}$ analysis. Each coral sample $(\sim 1 \mathrm{mg})$ is dissolved in $6 \mathrm{~mL}$ of $1 \%(\mathrm{v} / \mathrm{v})$ plasma-grade $\mathrm{HNO}_{3}$ and spiked with $60 \mu \mathrm{L}$ of internal standard solution. We did not perform rigorous oxidative cleaning procedures [e.g., Lea and Boyle, 1993] on our coral samples prior to analysis. Analytical results are reported in concentrations, which permit direct assessment of any changes in instrument response with time because direct comparisons can made between measured and known concentrations of gravimetric standards. Drift corrections and conversion of measured concentrations to molar ratios are done offline in a simple spreadsheet.

[9] Analyses of our gravimetric solutions yield precision for $\mathrm{Mg} / \mathrm{Ca}$ and $\mathrm{Sr} / \mathrm{Ca}$ that is better than $0.33 \%(1 \sigma)$ and better than $0.60 \%$ for $\mathrm{U} / \mathrm{Ca}$ and $\mathrm{Ba} / \mathrm{Ca}(1 \sigma)$. Analyses of two coral standards, Amédée Island Coral Standard (AICS; Porites lutea [this study]) and Davies Reef Coral Standard (DRCS; Porites mayeri [Sinclair et al., 1998]), yield precision for $\mathrm{Mg} / \mathrm{Ca}$ and $\mathrm{Sr} / \mathrm{Ca}$ that is better than $0.40 \%(1 \sigma)$ and better than $0.75 \%$ for $\mathrm{U} / \mathrm{Ca}$ and $\mathrm{Ba} / \mathrm{Ca}(1 \sigma)$. We observe differences between element concentrations and molar ratios that we determined on DRCS and with those reported by Sinclair et al. [1998] for their solution analysis on bulk sample. These differences may be the result of methodological differences or heterogeneity in the DRCS. However, we can not isolate the exact cause of this difference, but these differences do serve to highlight the need for a wellcharacterized, interlaboratory coral standard.

\subsection{Oxygen Isotope Analysis}

[10] Stable isotopic analyses were performed at the University of Michigan. Prior to isotopic analysis, powdered coralline aragonite samples were vacuum roasted for one hour at $200^{\circ} \mathrm{C}$. Samples were reacted with anhydrous phosphoric acid at $75^{\circ} \mathrm{C}$ in individual reaction vessels of a CarboKiel carbonate-extraction system coupled to the inlet of a MAT 251 mass spectrometer. Precision $( \pm 2 \sigma)$ was monitored by daily analyses of a powdered calcite standard (NBS-20) and was better than $0.08 \%$ for both oxygen and carbon. The average standard deviation of forty-six replicate analyses of coral samples is $0.10 \%$ for oxygen and $0.07 \%$ carbon. Values are reported in standard $\delta$ notation relative to VPDB after correction for the ${ }^{17} \mathrm{O}$ contribution.

\subsection{Data Analysis}

[11] Statistical analysis of the data was performed using the Macintosh programs Statview and JMP. Geochemical and environmental anomalies were calculated from the monthly time series by subtracting the monthly climatological means calculated between 1992 and 1968 from the appropriate individual monthly value of each variable.

[12] The ordinary least squares (OLS) regression technique (model I) has been commonly used to develop an empirical relationship between coral element/Ca and SST. In most cases SST is defined as the independent variable and coral element/Ca the dependent variable. This regression of $y$ on $x$ assumes error only in the measurement of the dependent variable; error in the independent variable is assumed to be zero. Alternatively, the reduced major axis (RMA) regression technique (model II) can also be used to develop an empirical relationship between coral element/Ca and SST. This regression technique assumes error in the measurement of both the dependent and independent variables and is considered to an appropriate technique to use with geologic data. The slope the equation produced by RMA regression equals the slope of the equation of OLS regression divided by the correlation coefficient [e.g., Cobb, 1998].

\section{Results}

[13] $\delta^{18} \mathrm{O}, \mathrm{Sr} / \mathrm{Ca}, \mathrm{Mg} / \mathrm{Ca}$, and $\mathrm{U} / \mathrm{Ca}$ records display seasonal cyclicity and all of the signals are well matched over the $15.45 \mathrm{~mm}$ of sampling overlap (Figure 1). The uppermost portion of the $\mathrm{Mg} / \mathrm{Ca}$ and $\mathrm{U} / \mathrm{Ca}$ profiles (Figures $1 \mathrm{c}$ and 1d) are noncyclical and have absolute values that are unlikely to reflect primary environmental processes (e.g., SST variation). Noncyclical $\mathrm{Mg} / \mathrm{Ca}$ and $\mathrm{U} / \mathrm{Ca}$ variations are restricted to the top of the coral head, a position that is consistent with the influence of residual organic matter within the coral skeleton on the $\mathrm{Mg} / \mathrm{Ca}$ and $\mathrm{U} / \mathrm{Ca}$ signal. Contamination of the signal in the uppermost portion of the coral slab may be avoidable in future studies by cleaning the coral samples [e.g., Lea and Boyle, 1993] prior to analysis. However, a host of other possibilities exist for such compositional heterogeneity (e.g., microborings, contaminants, 

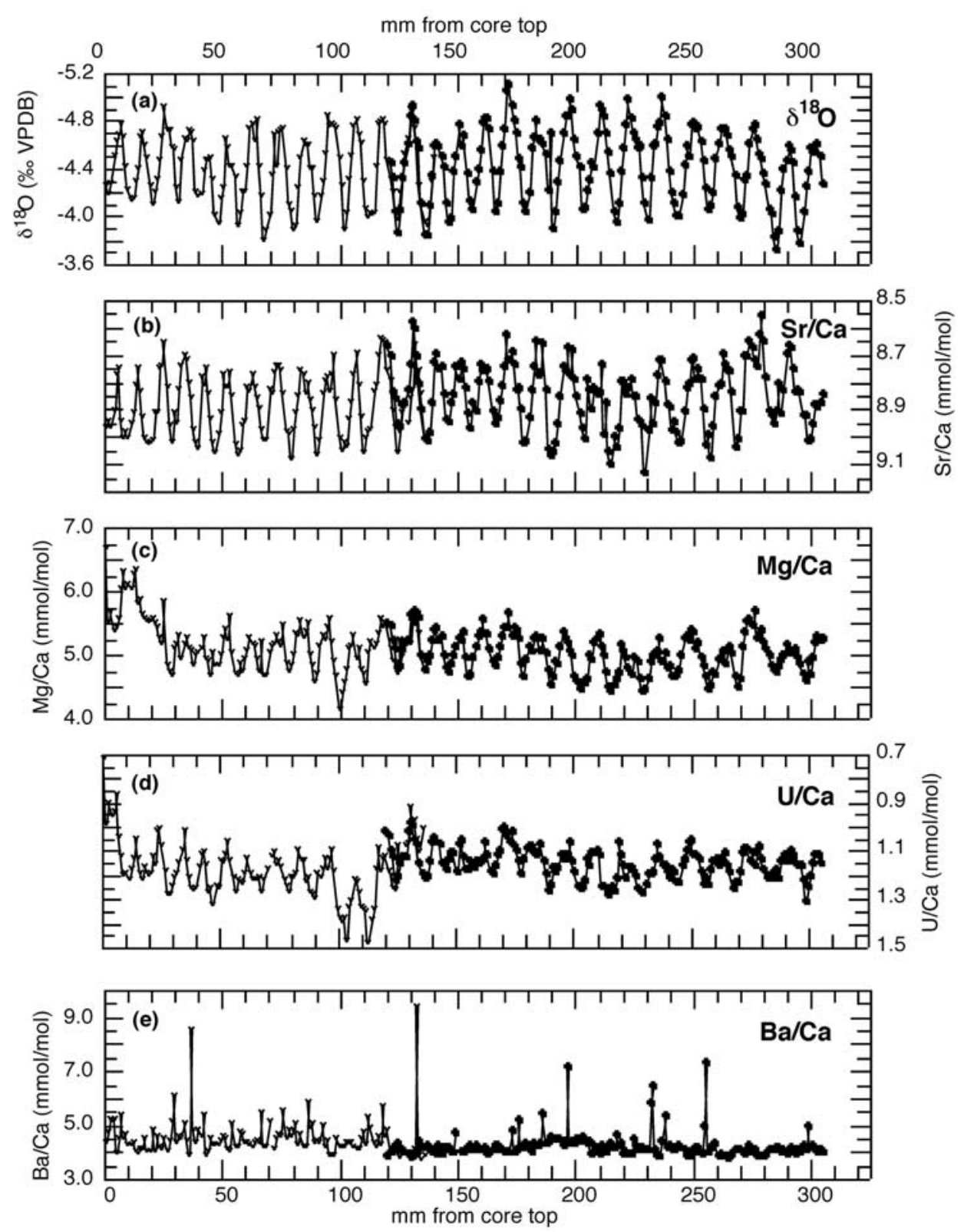

Figure 1. Element/Ca variations versus depth along sampling paths $\mathrm{A}(\mathrm{X}$ symbol) and $\mathrm{B}$ (closed squares symbol) in a Porites coral from New Caledonia. (a) Oxygen isotopic variations, (b) $\mathrm{Sr} / \mathrm{Ca}$ variations, (c) $\mathrm{Mg} / \mathrm{Ca}$ variations, (d) $\mathrm{U} / \mathrm{Ca}$ variations, and (e) $\mathrm{Ba} / \mathrm{Ca}$ variations. Cyclical variations are observed in all geochemical variables except for $\mathrm{Ba} / \mathrm{Ca}$.

and nonaragonite mineral phases [see, Sinclair et al., 1998]).

[14] In general, the monthly elemental records from the New Caledonia coral correlate well with each other (Table 2) and with monthly SST variations (Table 2; Figure 2). However, we expected greater levels of covariation of $\mathrm{Sr} /$ $\mathrm{Ca}, \mathrm{Mg} / \mathrm{Ca}$ and $\mathrm{U} / \mathrm{Ca}$, as variations in each have been attributed to be driven by variations in SST [e.g., Beck et al., 1992; Min et al., 1995; Mitsuguchi et al., 1996]. We do note that yearly correlation coefficients between the different elemental ratios and SST vary as a function of time. $\mathrm{Sr} /$
$\mathrm{Ca}$ variations are always highly correlated with SST, whereas $\mathrm{Mg} / \mathrm{Ca}$ and $\mathrm{U} / \mathrm{Ca}$ are sometimes highly correlated with SST (e.g., 1980-1978) and sometimes not (e.g., 1985-1981). Because elemental ratios are determined simultaneously from a single sample, the variability in goodness of fit between SST and $\mathrm{U} / \mathrm{Ca}$ and $\mathrm{Mg} / \mathrm{Ca}$ suggests that variations in these ratios are not solely a function of SST variations.

[15] Lastly, we note that strong relationships between monthly proxy and monthly instrumental records can be misleading due to the impact that the extremes of the 
Table 2. Linear, Zero-Lag Ordinary Least Square Correlation Coefficients Between Monthly Geochemical and SST Time Series ${ }^{\mathrm{a}}$

$\delta^{18} \mathrm{O} \%, \quad \delta^{13} \mathrm{C} \%, \quad \mathrm{Sr} / \mathrm{Ca}, \quad \mathrm{Mg} / \mathrm{Ca}, \quad \mathrm{U} / \mathrm{Ca}, \quad \mathrm{Ba} / \mathrm{Ca}, \quad \mathrm{SST}$, PDB PDB $\mathrm{mmol} / \mathrm{mol} \mathrm{mmol} / \mathrm{mol} \mu \mathrm{mol} / \mathrm{mol} \mathrm{mmol} / \mathrm{mol}^{\circ} \mathrm{C}^{\mathrm{b}}$

\begin{tabular}{lrrrrrrr}
\hline$\delta^{18} \mathrm{O}$ & & & & & & & \\
$\delta^{13} \mathrm{C}$ & 0.3 & & & & & & \\
$\mathrm{Sr} / \mathrm{Ca}$ & $\mathbf{0 . 8 5}$ & 0.2 & & & & & \\
$\mathrm{Mg} / \mathrm{Ca}$ & -0.66 & $-\mathbf{0 . 3}$ & $-\mathbf{0 . 7 8}$ & & & \\
$\mathrm{U} / \mathrm{Ca}$ & $\mathbf{0 . 6}$ & 0.23 & $\mathbf{0 . 7 2}$ & $-\mathbf{0 . 7 4}$ & & & \\
$\mathrm{Ba} / \mathrm{Ca}$ & 0.06 & -0.14 & 0.08 & 0.01 & 0.05 & & \\
$\mathrm{SST}^{\mathrm{b}}$ & $-\mathbf{0 . 9}$ & -0.14 & $\mathbf{- 0 . 9 1}$ & $\mathbf{0 . 7 8}$ & $\mathbf{- 0 . 6 7}$ & -0.08 & \\
& $(-\mathbf{0 . 5 9})^{2}$ & & $(-\mathbf{0 . 7 4})$ & $(-0.55)$ & $(-\mathbf{0 . 6 8})$ & & \\
$\mathrm{SST}^{\mathrm{c}}$ & $-\mathbf{0 . 9}$ & -0.26 & $\mathbf{- 0 . 9 2}$ & $\mathbf{0 . 7 4}$ & $\mathbf{- 0 . 6 9}$ & -0.08 & $\mathbf{1}$ \\
\hline
\end{tabular}

${ }^{\text {a }}$ Values in bold are significant at the $99 \%$ confidence level. Values in parenthesis refer to results of comparison of mean annual time series.

${ }^{\mathrm{b}}$ From unpublished data, IRD-Noumea.

${ }^{\mathrm{c}}$ GISST2.3b data [Parker et al., 1995].

seasonal cycle have on the ordinary least squares correlation technique. An analysis of mean annual values frequently results in lower correlation coefficients but provides greater insight into the strength of the relationship between two variables (Table 2).

\section{1. $\mathrm{Sr} / \mathrm{Ca}$}

[16] Monthly $\mathrm{Sr} / \mathrm{Ca}$ variations correlate well with monthly SST variations both at the local $\left(\mathrm{r}^{2}=0.77, \mathrm{p}<0.0001\right)$ and $1^{\circ}$ by $1^{\circ}$ grid box scale $\left(r^{2}=0.77, p<0.0001\right.$; Table 2$)$. Monthly $\mathrm{Sr} / \mathrm{Ca}$ variations are also highly correlated with monthly $\delta^{18} \mathrm{O}\left(\mathrm{r}^{2}=0.77, \mathrm{p}<0.0001\right)$, monthly $\mathrm{Mg} / \mathrm{Ca}$ variations $\left(\mathrm{r}^{2}=0.65, \mathrm{p}<0.0001\right.$ and monthly $\mathrm{U} / \mathrm{Ca}\left(\mathrm{r}^{2}=\right.$ $0.56, p<0.0001$; Table 2). Cast in terms of anomalies after removing the annual cycle, $\mathrm{Sr} / \mathrm{Ca}$ is positively correlated with $\delta^{18} \mathrm{O}$ and $\mathrm{U} / \mathrm{Ca}$ and negatively correlated with SST and $\mathrm{Mg} / \mathrm{Ca}$. OLS and RMA regression techniques yield $\mathrm{Sr} / \mathrm{Ca}-$ SST calibration equations for the coral Sr/Ca-SST relationship at New Caledonia (Table 3) that are similar to those generated in previous studies using different methods. Indeed, the slope values for $\mathrm{Sr} / \mathrm{Ca}-\mathrm{SST}$ reported in Table 3 and within error of the average slope value of $0.0620 \pm$ 0.014 reported by Gagan et al. [2000] in a recent summary of the existing published literature on coral $\mathrm{Sr} / \mathrm{Ca}$ measurements.

\section{2. $\mathrm{Mg} / \mathrm{Ca}$}

[17] Seasonal variations of $\mathrm{Mg} / \mathrm{Ca}$ are clearly evident (Figure 2c) and are moderately correlated with local SST variations at the monthly $(\mathrm{r}=0.78)$ and annual $(\mathrm{r}=0.55)$ timescales (Table 2). The slope of our $\mathrm{Mg} / \mathrm{Ca}-\mathrm{SST}$ calibration using OLS regression is $0.105( \pm 0.013)$ for comparison with local SST and is $0.125( \pm 0.014)$ for comparison with gridded SST (Table 3). Other estimates of the slope of the Porites coral $\mathrm{Mg} / \mathrm{Ca}-\mathrm{SST}$ relationship vary from 0.129 [Mitsuguchi et al., 1996], 0.140 [Sinclair et al., 1998], 0.088 [Fallon et al., 1999], and 0.164 [Wei et al., 2000]. Other than citing the usual suspects such as vital effects, microenvironmental variation, coral collection and sampling protocols, etc., we can shed no additional light on why there are differences in the slope of the various $\mathrm{Mg} / \mathrm{Ca}-\mathrm{SST}$ calibrations. Other workers have noted that widespread use of coral $\mathrm{Mg} / \mathrm{Ca}$ variations in paleothermometry may be limited [Shen et al., 1992; Schrag, 1999] and our results supports this notion.

\section{3. $\mathrm{U} / \mathrm{Ca}$}

[18] U/Ca variations are cyclical in nature and comparison with local SST data yields a correlation between the two records of $\sim-0.68$ at the monthly timescale and -0.68 at the annual timescale (Table 2). Our U/Ca-based reconstructions of SST variations show some large discrepancies with the observed local SST. For example, our reconstruction indicates winter temperatures of $\sim 15^{\circ} \mathrm{C}$ in 1981 and 1982 (Figure $2 \mathrm{~d}$ ), values that are $\sim 5^{\circ} \mathrm{C}$ colder than those observed in the local record of SST. The slope of our U/ Ca-SST calibration using OLS regression is -0.029 $( \pm 0.005)$, when regressed against local SST and is -0.032 $( \pm 0.004)$, when regressed against gridded SST (Table 3$)$. Other estimates of the slope of the Porites coral U/Ca-SST relationship vary from 0.045 [Min et al., 1995], 0.046 [Sinclair et al., 1998], and 0.044 [Fallon et al., 1999]. These slope values are in good agreement with those estimated using RMA regression in this study (Table 3). Additional work is needed to identify the source of the slope discrepancies among the various $\mathrm{U} / \mathrm{Ca}$ studies.

[19] We can also compare our U/Ca data with those of Min et al. [1995], who analyzed a Poriteslobata coral from offshore of the Amédée Lighthouse, New Caledonia. Five years $(1983-1987)$ of near monthly U/Ca determinations by TIMS is 1.161 [Min et al., 1995], whereas the U/Ca determinations by SF-ICP-MS is 1.192 over the same time interval. This $2.72 \%$ difference in $\mathrm{U} / \mathrm{Ca}$ is equivalent to a $\sim 1^{\circ} \mathrm{C}$ SST difference between the two records. These two $\mathrm{U} / \mathrm{Ca}$ records are from the same location, but are not from the same coral. Some of the observed difference may be due to real variability between the two corals as a robust analysis of elemental ratio variations within multiple coral heads from the same location has not been performed; such differences have been documented for coral oxygen isotope records [e.g., Linsley et al., 1999]. The observed offset in U/ $\mathrm{Ca}$ ratios might also reflect an accuracy offset between the two laboratories. This offset also demonstrates the need for the development of well-characterized laboratory standards for elemental ratio analyses of coral skeletons.

[20] The covariation of monthly U/Ca with monthly $\mathrm{Sr} / \mathrm{Ca}$ $(\mathrm{r}=0.91)$ documented by Min et al. [1995] is also observed in this study $(r=0.72)$, which is consistent with the notion that both ratios respond to variations in SST. However, previous work [Min et al., 1995; Shen and Dunbar, 1995; Cardinal et al., 2001] has also demonstrated that variations in coral U/Ca ratios are driven by SST, SSS, alkalinity and uranium speciation. The incorporation of uranium in the coral skeleton from seawater is unlikely to occur by simple substitution for calcium in the coral aragonite because of the large differences in ionic radii and valence between the two. Reeder et al. [2000] have recently demonstrated that uranium is incorporated into aragonite as part of the uranyl triscarbonate complex (UTC), which has a valence of -4 . The UTC inhabits part of the structure corresponding to a $\mathrm{Ca}$ polyhedron and some of the coordinated carbonate groups [Reeder et al., 2000]. Lastly because the aqueous uranyl carbonate species incorporated into aragonite is an 

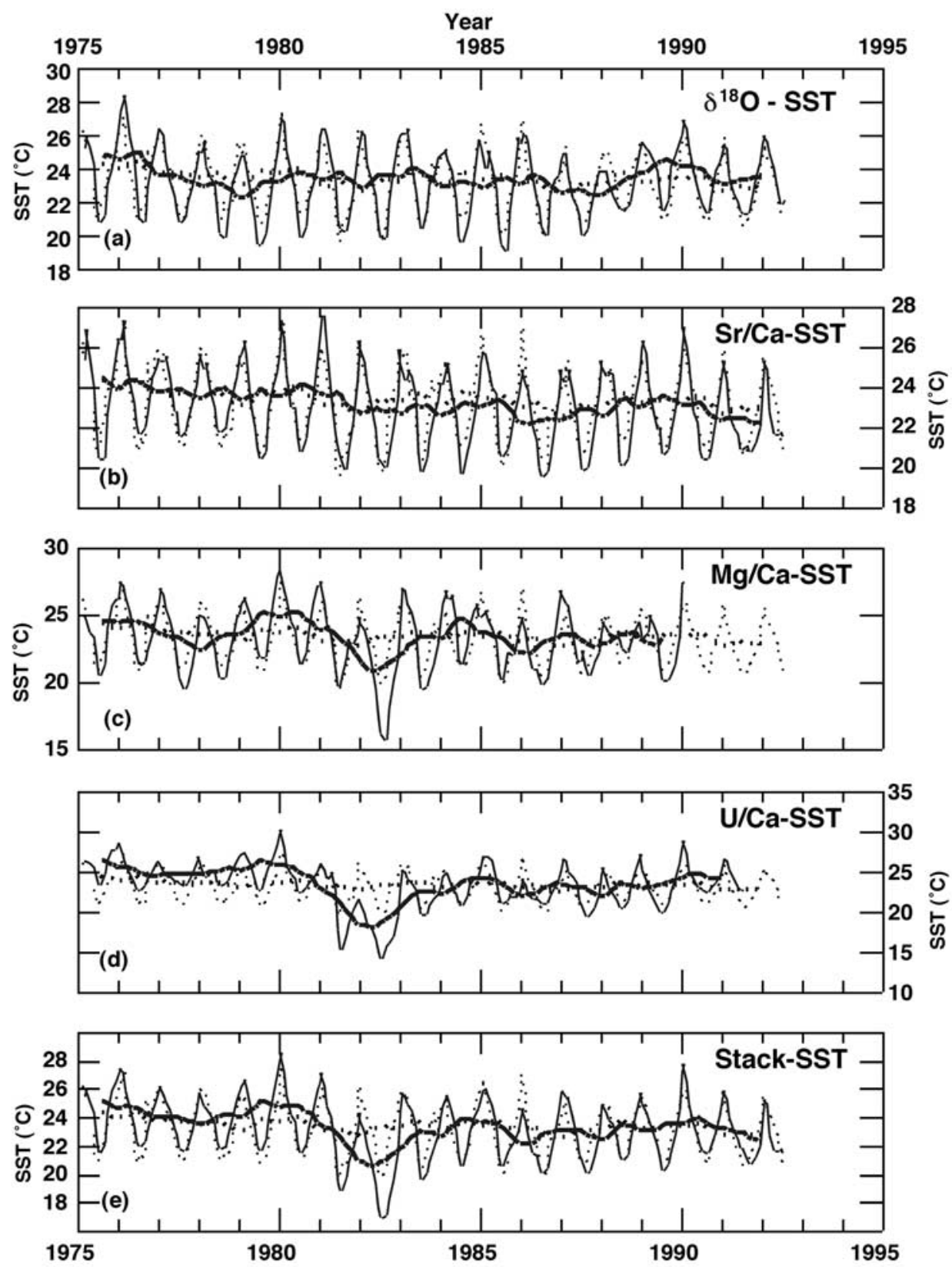

Figure 2. Monthly (thin lines) and mean annual (thick lines) proxy-based SST variations (solid lines) versus instrumental SST variations (dashed lines). (a) Oxygen isotope proxy, (b) $\mathrm{Sr} / \mathrm{Ca}$ proxy, (c) $\mathrm{Mg} / \mathrm{Ca}$ proxy, (d) U/Ca proxy, and (e) stacked $\mathrm{Sr} / \mathrm{Ca}-\mathrm{Mg} / \mathrm{Ca}-\mathrm{U} / \mathrm{Ca}$ proxy. $\mathrm{Sr} / \mathrm{Ca}-$ based estimates of SST provide the best agreement with instrumental record at both the monthly $(r=-0.92)$ and annual $(r=-0.74)$ time scales. Stacking of $\mathrm{Sr} / \mathrm{Ca}-\mathrm{Mg} / \mathrm{Ca}-\mathrm{U} / \mathrm{Ca}$ records produces a proxy SST time series that has greater standard error than the individual $\mathrm{Sr} / \mathrm{Ca}-\mathrm{SST}$ time series (cf., OLS standard error of $1.16^{\circ} \mathrm{C}$ vs. $0.86^{\circ} \mathrm{C}$ ).

anion and bears no geometric similarity to divalent calcium [Reeder et al., 2000], perhaps it is not surprising that coralline $\mathrm{U} / \mathrm{Ca}$ ratios display variations that do not simply mimic SST variations.

\section{4. $\mathrm{Ba} / \mathrm{Ca}$}

[21] The $\mathrm{Ba} / \mathrm{Ca}$ record contains several large excursions to values several fold greater than background levels (Figure 1e). Abrupt increases in $\mathrm{Ba} / \mathrm{Ca}$ ratios have been noted in other coral studies [e.g., Pingitore et al., 1989; Hart and Cohen, 1996; Tudhope et al., 1996] and their origin has usually been attributed to the presence of Ba-rich organic matter. A similar explanation may be appropriate for the elevated $\mathrm{Ba} / \mathrm{Ca}$ ratios observed in this coral from New Caledonia as we did not perform rigorous oxidative cleaning procedures [e.g., Lea and Boyle, 1993] on our coral samples prior to analysis. Although we note that extensive oxidative cleaning of samples by Tudhope et al. 
Table 3. Coral Element/Ca-SST Calibrations at New Caledonia

\begin{tabular}{|c|c|c|c|c|c|}
\hline Local SST & Slope & Intercept & $\mathrm{R}^{2}$ & $\mathrm{SE}^{\mathrm{a}}$ Ratio & $\mathrm{SE}^{\circ} \mathrm{C}$ \\
\hline \multicolumn{6}{|c|}{$\mathrm{Sr} / \mathrm{Ca}(\mathrm{mmol} / \mathrm{mol}), n=212$} \\
\hline OLS & -0.052 & 10.073 & 0.84 & 0.045 & 0.86 \\
\hline RMA & -0.057 & 10.12 & 0.84 & 0.045 & 0.78 \\
\hline \multicolumn{6}{|c|}{$\mathrm{Mg} / \mathrm{Ca}(\mathrm{mmol} / \mathrm{mol}), n=182$} \\
\hline OLS & 0.105 & 2.638 & 0.61 & 0.155 & 1.48 \\
\hline RMA & 0.133 & 1.962 & 0.61 & 0.155 & 1.17 \\
\hline \multicolumn{6}{|c|}{$\mathrm{U} / \mathrm{Ca}(\mu \mathrm{mol} / \mathrm{mol}), n=200$} \\
\hline OLS & -0.029 & 1.847 & 0.44 & 0.06 & 2.09 \\
\hline RMA & -0.044 & 2.188 & 0.44 & 0.06 & 1.37 \\
\hline Gridded SST & Slope & Intercept & $\mathrm{R}^{2}$ & SE Ratio & $\mathrm{SE}^{\circ} \mathrm{C}$ \\
\hline \multicolumn{6}{|c|}{$\mathrm{Sr} / \mathrm{Ca}(\mathrm{mmol} / \mathrm{mol}), n=293$} \\
\hline OLS & -0.061 & 10.383 & 0.84 & 0.043 & 0.71 \\
\hline RMA & -0.067 & 10.524 & 0.84 & 0.043 & 0.65 \\
\hline \multicolumn{6}{|c|}{$\mathrm{Mg} / \mathrm{Ca}(\mathrm{mmol} / \mathrm{mol}), n=266$} \\
\hline OLS & 0.125 & 1.941 & 0.55 & 0.181 & 1.45 \\
\hline RMA & 0.168 & 0.873 & 0.55 & 0.181 & 1.08 \\
\hline \multicolumn{6}{|c|}{$\mathrm{U} / \mathrm{Ca}(\mu \mathrm{mol} / \mathrm{mol}), n=284$} \\
\hline OLS & -0.032 & 1.953 & 0.47 & 0.054 & 1.68 \\
\hline RMA & -0.046 & 2.308 & 0.47 & 0.054 & 1.17 \\
\hline
\end{tabular}

${ }^{\mathrm{a}} \mathrm{SE}$, standard error of regression $\mathrm{Y}$ on $\mathrm{X}$.

[1996] was not able to reduce the observed excursions to elevated levels of $\mathrm{Ba} / \mathrm{Ca}$.

\section{Discussion}

\subsection{Fidelity of the SST Proxies}

[22] There are now a number of studies that have reported results on the measurements of $\mathrm{Sr} / \mathrm{Ca}, \mathrm{Mg} / \mathrm{Ca}$ and $\mathrm{U} / \mathrm{Ca}$ in coral skeletons using a wide range of analytical instrumentation (see Table 1). The overwhelming majority of such studies have compared measured geochemical variations with SST records to generate empirical relationships between element/Ca ratios and SST. Although the general relationship between SST and element/Ca ratio variations is undeniable, questions remain about the robustness of this relationship and the skill with which proxy geochemical variations can be used to reconstruct past variations in SST.

[23] One manifestation of this robustness of proxy issue is the variability in the various calibration equations relating each element/Ca ratio to SST. Gagan et al. [2000] recently addressed the $\mathrm{Sr} / \mathrm{Ca}-\mathrm{SST}$ relationship and noted that offsets of up to $3.5^{\circ} \mathrm{C}$ do exist among the various regression equations; however the slopes of the calibration equations are remarkably similar (with one exception). Calibration offsets have also been noted for U/Ca-SST and $\mathrm{Mg} / \mathrm{Ca}-\mathrm{SST}$ [e.g., Fallon et al., 1999]. Eisenhauer et al. [1999] noted that in most cases the temperature offsets produced by using the previously published $\mathrm{Sr} / \mathrm{Ca}-\mathrm{SST}$ calibrations can be reconciled within $1{ }^{\circ} \mathrm{C}$ after correction for differences in seawater $\mathrm{Sr} / \mathrm{Ca}$ ratios and normalization to a common SST database. Averaging or stacking individual proxy SST records $(\mathrm{Sr} / \mathrm{Ca}, \mathrm{Mg} / \mathrm{Ca}$ and $\mathrm{U} / \mathrm{Ca}$ ) to generate a composite proxy SST record does not necessarily improve the proxy record if the signal-to-noise ratio in each proxy is highly variable. For example, stacking of $\mathrm{Sr} / \mathrm{Ca}-\mathrm{Mg} / \mathrm{Ca}-\mathrm{U} / \mathrm{Ca}$ records at New Caledonia produces a proxy SST time series that has greater standard error than the individual $\mathrm{Sr} / \mathrm{Ca}-\mathrm{SST}$ time series (cf. OLS standard error of $1.16^{\circ} \mathrm{C}$ versus $0.86^{\circ} \mathrm{C}$ ).

[24] The issue of precision and accuracy of the $\mathrm{Sr} / \mathrm{Ca}$ paleothermometer is one that has been raised in several studies [e.g., de Villiers et al., 1994; Gagan et al., 2000; Cardinal et al., 2001; Cohen et al., 2001, 2002]. Cohen et al. [2001] noted distinct differences between the $\mathrm{Sr} / \mathrm{Ca}-\mathrm{SST}$ relationship for daytime versus nighttime skeletal deposits, which they attributed to result from kinetic controls on calcification. In contrast, Swart et al. (Calibration of $\mathrm{Sr} / \mathrm{Ca}$ thermometry using the Caribbean coral Montastraea annularis, submitted to Geochemistry, Geophysics, Geosystems, 2002) concluded that kinetic effects have little impact on coral $\mathrm{Sr} / \mathrm{Ca}$ ratios. The observed differences in the $\mathrm{Sr} / \mathrm{Ca}-$ SST relationship may be the result of several factors including differences in coral collection and sampling protocols, lack of standardization of instrumental SSTs among calibration sites, interlaboratory differences in standard determination or $\mathrm{Sr} / \mathrm{Ca}$ spike calibrations, or it may reflect some real variability. Gagan et al. [2000] reviewed the issue and noted that with one exception, the slopes of the calibration equations are remarkably similar (mean $=0.062 \pm 0.014,2 \sigma$ ) .

[25] Clearly there is a need to better understand the biogeochemistry behind the $\mathrm{Sr} / \mathrm{Ca}-\mathrm{SST}$ relationship in corals. Micron-scale studies of coral skeletons [e.g., Allison, 1996a, 1996b; Hart and Cohen, 1996; Cohen et al., 2001, 2002] can shed some light into the darkness of elemental partitioning in response to biologically mediated precipitation of the coral aragonite. However, the fidelity of the $\mathrm{Sr} / \mathrm{Ca}-\mathrm{SST}$ proxy ultimately will be decided by quantitative evaluation of the goodness of fit between the observed and $\mathrm{Sr} / \mathrm{Ca}$-based predicted records of SST. We perform two such evaluations. First, we define the $\mathrm{Sr} / \mathrm{Ca}$-SST relationship at New Caledonia for the period 1992-1980 (i.e., the calibration interval). Next, we use the $\mathrm{Sr} / \mathrm{Ca}$-SST equation determined for the calibration interval to predict SST for the period 1979-1968 (i.e., the verification interval). The results of this calibration-verification exercise indicates that the misfit between the observed and predicted record of SST variations is the same for both time intervals, confirming the robustness of the calibration, and that the average error associated with this approach is $0.32 \pm 0.48^{\circ} \mathrm{C}(2 \sigma)$ (Figure 3). Second, we apply this calibration-verification technique to the recently published time series of coral $\mathrm{Sr} / \mathrm{Ca}$-SST variations at Rarotonga [Linsley et al., 2000]. The mean and standard deviation of the observed and predicted SST time series are indistinguishable from each other (Figure 4). The average misfit between observed and $\mathrm{Sr} / \mathrm{Ca}$-based predictions of SST between 1996 and 1951 is $0.29 \pm 0.46^{\circ} \mathrm{C}(2 \sigma)$ (Figure 4). The verification interval is not extended prior to 1950 because instrumental record is discontinuous prior to this time [Linsley et al., 2000]. The similarities in the mean, standard deviation and degree of misfit between observed and predicted SST, based on coral $\mathrm{Sr} / \mathrm{Ca}$ measurements at two sites, provides insights into the "paleoclimate" accuracy and precision of the coralbased SST proxy. We estimate that "paleoclimate" precision of the coral $\mathrm{Sr} / \mathrm{Ca}$-SST technique is $\sim 0.3^{\circ} \pm 0.5(2 \sigma)$.

[26] In more general terms, one can find issue with most, if not all paleoceanographic/paleoclimatic proxies of tem- 


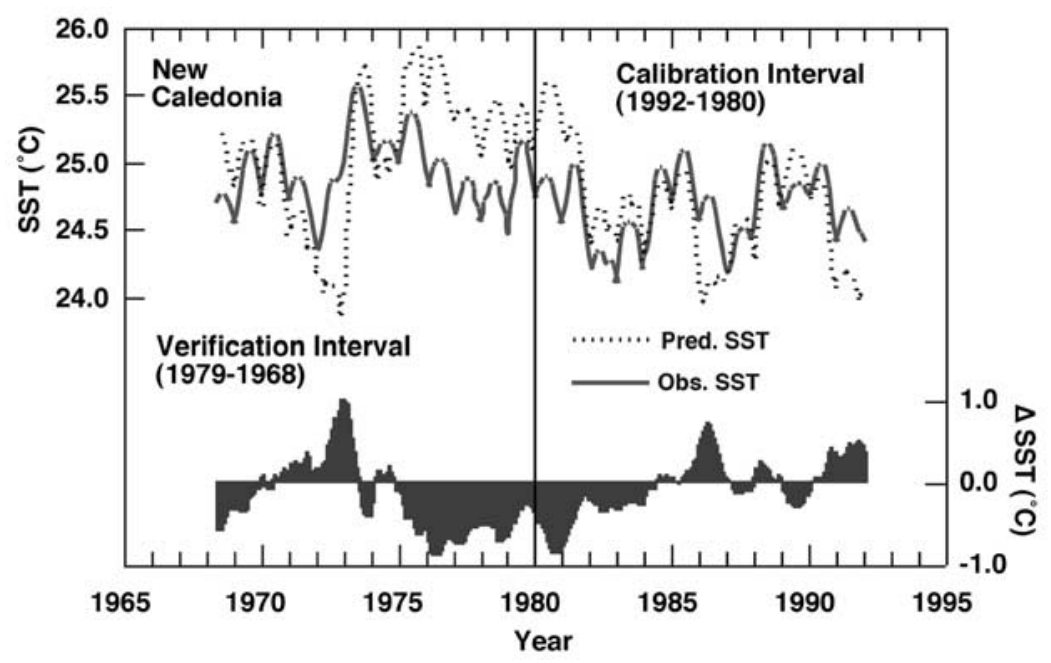

Figure 3. Monthly observed (solid line) versus predicted (dashed line) SST at New Caledonia. Both records have been smoothed using a 13-point window. The observed SST record is from the $22^{\circ} \mathrm{S}, 166^{\circ} \mathrm{E}$ grid box from the GISST2.3b database [Parker et al., 1995]. The predicted SST record is derived from coral $\mathrm{Sr} / \mathrm{Ca}$ determinations. The coral $\mathrm{Sr} / \mathrm{Ca}$-SST relationship was calibrated for the 1992-1980 period and verified for the 1979-1968 interval. The bar graph on the bottom indicates the misfit between observed and predicted SST values. The absolute value of the average misfit between these two records is $0.32 \pm 0.48^{\circ} \mathrm{C}(2 \sigma)$.

perature (e.g., $\delta^{18} \mathrm{O}$ in biogenic carbonate, $\mathrm{Sr} / \mathrm{Ca}$ in corals, $\mathrm{Mg} / \mathrm{Ca}$ in foraminifera, alkenones in marine sediments). There tends to be a natural maturation process in temperature-proxy development and assessment, whereby the initial euphoria of a potential panacea fades into the reality that a multiproxy approach is best and that all proxies must be used judiciously. $\mathrm{Sr} / \mathrm{Ca}$ ratios in coral skeletons are no different.
However, one must be careful about "not throwing the baby out with the bath water" on the proxy calibration issue. Calibration is only a first step in determining the fidelity of a climate proxy. The paleoclimate utility of a proxy is ultimately determined through verification with an independent record of environmental variability. The calibration-verification exercise, so routinely performed by other groups of paleo-

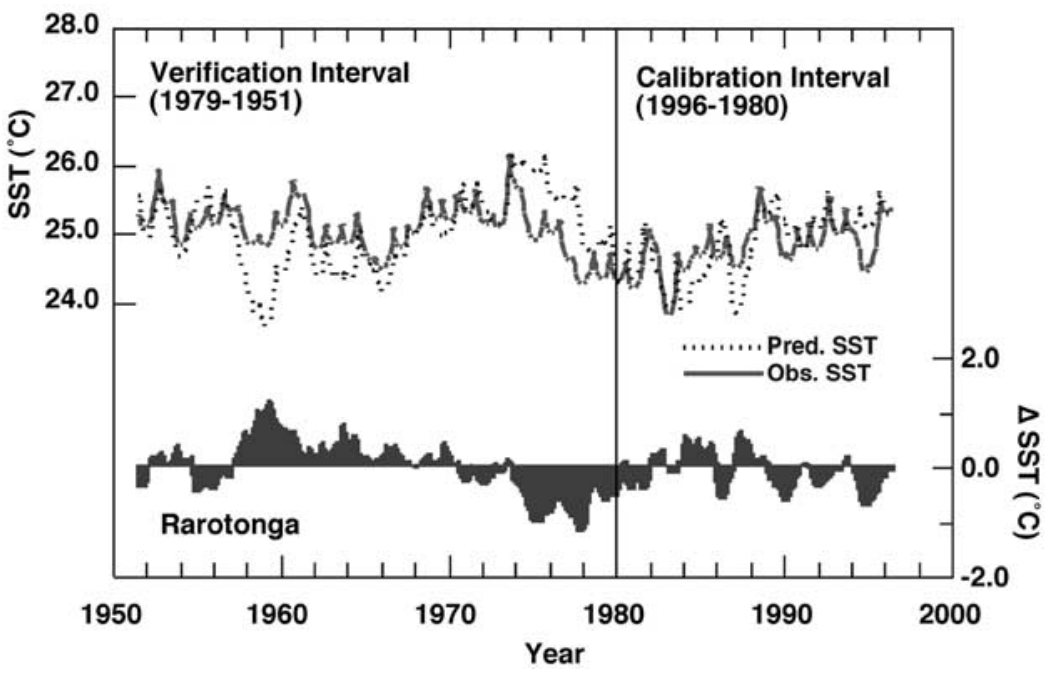

Figure 4. Monthly observed (solid line) versus predicted (dashed line) SST at Rarotonga. Both records have been smoothed using a 13-point window. The observed SST record is from the $22^{\circ} \mathrm{S}, 160^{\circ} \mathrm{W}$ grid box from the GISST2.3b database [Parker et al., 1995]. The predicted SST record is derived from coral $\mathrm{Sr} / \mathrm{Ca}$ determinations of Linsley et al. [2000]. The coral $\mathrm{Sr} / \mathrm{Ca}$-SST relationship was calibrated for the 1992-1980 period and verified for the 1979-1951 interval. The bar graph on the bottom indicates the misfit between observed and predicted SST values. The absolute value of the average misfit between these two records is $0.29 \pm 0.46^{\circ} \mathrm{C}(2 \sigma)$. 


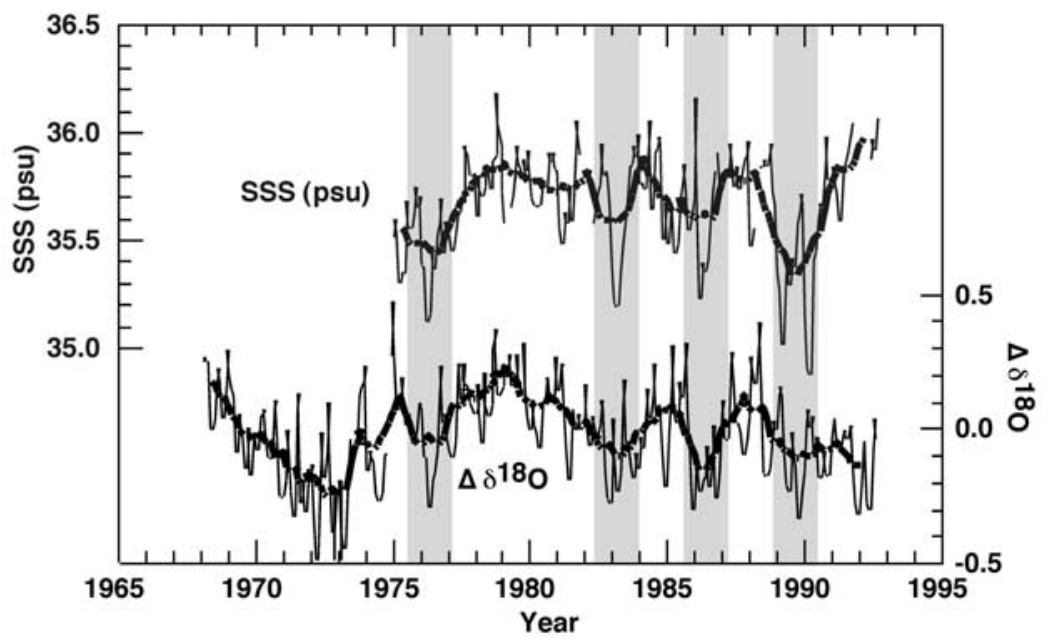

Figure 5. Monthly variations in sea-surface salinity (SSS, dashed lines) and coral $\Delta \delta^{18} \mathrm{O}$ (solid lines) versus time. $\Delta \delta^{18} \mathrm{O}$ is defined by the equation $\Delta \delta^{18} \mathrm{O}=\partial \delta^{18} \mathrm{O} / \partial \mathrm{T} *\left(\mathrm{~T}_{\delta 18 \mathrm{O}}-\mathrm{T}_{\mathrm{Sr} / \mathrm{Ca}}\right)$, where $\partial \delta^{18} \mathrm{O}$ is the temperature-dependent fractionation factor for Porites [Gagan et al., 1998]. Thick lines are the result of smoothing the monthly time series to accentuate interannual changes in the two signals. Shaded vertical bars highlight four periods of fresher-than-average SSS that coincide with negative excursions in $\Delta \delta^{18} \mathrm{O}$. The overall agreement, especially at the interannual scale, between observed SSS variations and proxybased predictions of variations in seawater $\delta^{18} \mathrm{O}$ at New Caledonia is consistent with the results of studies of corals from the Great Barrier Reef [e.g., Gagan et al., 1998].

climate workers (e.g., dendrochronologists), needs to become an integral part of coral-based climate reconstructions.

\subsection{A Coupled-Proxy Approach to Environmental Variations at the Sea Surface}

[27] Coupled measurements of coral skeletal $\mathrm{Sr} / \mathrm{Ca}$ and $\delta^{18} \mathrm{O}$ have been used in the past to isolate the thermal and hydrologic components of the coral $\delta^{18} \mathrm{O}$ signal by removing the thermal signal based on $\mathrm{Sr} / \mathrm{Ca}$ determinations [McCulloch et al., 1994; Gagan et al., 1998]. Changes in seawater $\delta^{18} \mathrm{O}$ can be inferred from the residual $\delta^{18} \mathrm{O}$ signal $\Delta \delta^{18} \mathrm{O}=\partial \delta^{18} \mathrm{O} / \partial \mathrm{T} *\left[\mathrm{~T}_{\delta 18 \mathrm{O}}-\mathrm{T}_{\mathrm{Sr} / \mathrm{Ca}}\right]$ [Gagan et al., 1998], and these changes can be related to variations in SSS.

[28] Given the rarity of long time series of SSS variations of the tropical oceans, the $>15$ year, daily SSS record at New Caledonia presents a unique opportunity to evaluate the relationship between residual $\delta^{18} \mathrm{O}$ and SSS. SSS ranges from a low of 35.3 in March to a high of 35.9 in October offshore of the Amédée Lighthouse. Interannual SSS anomalies associated with ENSO are of similar magnitude as, or greater than, mean seasonal changes [Delcroix and Lenormand, 1997]. The signature of ENSO in New Caledonia is as follows: the ENSO warm phase results in cold SST anomalies and saltier-than-average SSS anomalies, whereas the ENSO cold phase results in warm SST anomalies and fresher-than-average SSS anomalies [Delcroix and Lenormand, 1997]. The ENSO warm phase SSS anomaly at New Caledonia reaches a maximum in correlation with the SOI index at a lag of 9 months, a value that is consistent with the timing, relative to the SOI index, of negative rainfall anomalies in the area [Ropelewski and Halpert, 1987].

[29] Four prominent negative SSS anomalies (fresherthan-average conditions) are clearly evident in the instrumental SSS record (Figure 5). Each of these anomalies is also observed as negative anomalies in the record of residual $\delta^{18} \mathrm{O}$ (Figure 5). The overall agreement in the pattern of variation between the observed and proxy signal lends support to the notion that coupled measurements of coral skeletal $\mathrm{Sr} / \mathrm{Ca}$ and $\delta^{18} \mathrm{O}$ can be used to reconstruct SST and $\delta^{18} \mathrm{O}$ seawater variations.

\section{Conclusions}

[30] Multiple elemental ratio measurements were made using sector field inductively coupled plasma mass spectrometry (SF-ICP-MS) techniques, yielding precision of $<0.40 \% \mathrm{RSD}(1 \sigma)$ for $\mathrm{Mg} / \mathrm{Ca}$ and $\mathrm{Sr} / \mathrm{Ca}$ and $<0.75 \% \mathrm{RSD}$ $(1 \sigma)$ for $\mathrm{U} / \mathrm{Ca}$ and $\mathrm{Ba} / \mathrm{Ca}$. We coupled these measurements with stable isotopic measurements on a Porites coral head from offshore of the Amédée Lighthouse, New Caledonia to produce a monthly resolved, 25-year record of geochemical variations.

[31] Our results are consistent with the notion that $\mathrm{Sr} / \mathrm{Ca}$ is a robust "coral paleothermometer," as confirmed by calibration and verification. Coral $\mathrm{U} / \mathrm{Ca}$ and $\mathrm{Mg} / \mathrm{Ca}$ ratios at New Caledonia are sometimes highly correlated with SST and sometimes not, suggesting that variations in these ratios are not a simple function of SST variations. Indeed, stacking of $\mathrm{Sr} / \mathrm{Ca}-\mathrm{Mg} / \mathrm{Ca}-\mathrm{U} / \mathrm{Ca}$ records produces a proxy SST time series that has greater standard error than the individual $\mathrm{Sr} /$ Ca-SST time series (cf. OLS standard error of $1.16^{\circ} \mathrm{C}$ versus $0.86^{\circ} \mathrm{C}$ ). Coral $\mathrm{Ba} / \mathrm{Ca}$ ratios at New Caledonia are not easily interpreted in terms of environmental variability. However, this ratio does have utility at other localities where there is a pronounced seawater signal in $\mathrm{Ba} / \mathrm{Ca}$. Coupled measurements of coral skeletal $\mathrm{Sr} / \mathrm{Ca}$ and $\delta^{18} \mathrm{O}$ continue to show promise as a means to reconstruct SST and $\delta^{18} \mathrm{O}$ seawater variations $(\mathrm{SSS})$ in the past. 
[32] The precision and accuracy of the $\mathrm{Sr} / \mathrm{Ca}$ paleothermometer has been raised in several studies [e.g., de Villiers et al., 1994; Gagan et al., 2000; Cardinal et al., 2001; Cohen et al., 2001, 2002]. Much of the concern has focused on the variability of the empirically derived $\mathrm{Sr} / \mathrm{Ca}$-SST relationship and the mechanisms proposed to explain this variability. The adoption of a "standard" analytical protocol for coral $\mathrm{Sr} / \mathrm{Ca}$ determinations would produce less variability in the various calibration equations for $\mathrm{Sr} / \mathrm{Ca}-\mathrm{SST}$. This protocol should include measurement of a well-characterized, interlaboratory standard (i.e., an NBS19-equivalent for coral $\mathrm{Sr} / \mathrm{Ca}$ ), measurement of seawater $\mathrm{Sr} / \mathrm{Ca}$ ratios and normalization to an accepted value for seawater $\mathrm{Sr} / \mathrm{Ca}$, and normalization to a single, SST data set. However, calibration is only a first step in determining the fidelity of the coral $\mathrm{Sr} / \mathrm{Ca}-\mathrm{SST}$ proxy. The utility of a paleoclimate proxy is ultimately determined through verification with an independent record of environmental variability. The cali- bration-verification exercise, so routinely performed by other paleoclimate groups (e.g., dendrochronologists), needs to become an integral part of coral-based climate reconstructions. We performed such calibration-verification exercises using instrumental SST data and coral $\mathrm{Sr} / \mathrm{Ca}$ data determined at New Caledonia and Rarotonga [Linsley et al., 2000]. The "paleoclimate" accuracy of the coral Sr/Ca-SST technique is judged to be robust and the precision of the technique is judged to be $\sim 0.3^{\circ} \pm 0.5(2 \sigma)$.

[33] Acknowledgments. This research was performed during the sabbatical leave of TMQ at UCSC and he would like to thank the faculty, students and staff of the Earth and Marine Science Boards for their hospitality. Powdered coral sample "standards" were provided by Malcolm McCulloch for Davies Reef, GBR and Thierry Corrège for Amédée Lighthouse reef. We also thank Peter Harries, Hali Kilbourne, and Jennifer Smith for reading earlier versions of this manuscript and the journal reviewers for the insightful comments. This research was supported in part by awards to TMQ from NSF-Earth System History (OCE-9727414) and NOAA-Paleoclimatology Program (NA76GP0505).

\section{References}

Alibert, C., and M. T. McCulloch, Strontium/calcium ratios in modern Porites corals from the Great Barrier Reef as a proxy for sea surface temperature: Calibration of the thermometer and monitoring of ENSO, Paleoceanography, 12, 345-363, 1997.

Allison, N., Comparative determinations of trace and minor elements in coral aragonite by ion microprobe analyses, with preliminary results from Phuket, southern Thailand, Geochim. Cosmochim. Acta, 60, 3457-3470, 1996a.

Allison, N., Geochemical anomalies in coral skeletons and their possible implications for paleoenvironmental analyses, Mar. Chem., 55, 367-379, 1996b.

Allison, N., and A. W. Tudhope, Nature and significance of geochemical variations in coral skeletons as determined by ion microprobe analysis, in Proceedings of the 7th International Coral Reef Symposium, pp. 173-178, Int. Soc. for Reef Studies, Lawrence, Kans., 1992.

Beck, J. W., R. L. Edwards, E. Ito, F. W. Taylor, J. Recy, F. Rougerie, P. Joannot, and C. Henin, Sea-surface temperature from coral skeletal $\mathrm{Sr} /$ Ca ratios, Science, 257, 64-647, 1992.

Cardinal, D., B. Hamelin, E. Bard, and J. Pätzold, $\mathrm{Sr} / \mathrm{Ca}, \mathrm{U} / \mathrm{Ca}$ and $18 \mathrm{O}$ records in recent massive corals from Bermuda: Relationships with sea surface temperature, Chem. Geol., $176,213-233,2001$

Cobb, G. W., Introduction to Design and Analysis of Experiments, Springer-Verlag, New York, 1998.

Cohen, A. L., G. D. Layne, S. R. Hart, and P. S. Lobel, Kinetic control of skeletal $\mathrm{Sr} / \mathrm{Ca}$ in a symbiotic coral: Implications for the paleotemperature proxy, Paleoceanography, 16, 20-26, 2001.

Cohen, A. L., K. E. Owens, G. D. Layne, and N. Shimizu, The effect of algal symbionts on the accuracy of $\mathrm{Sr} / \mathrm{Ca}$ paleotemperatures from coral, Science, doi:10.1126/science1069330, 7 March 2002.

Crowley, T. J., T. M. Quinn, and W. T. Hyde, Validation of coral temperature calibrations, Paleoceanography, 14, 605-615, 1999.

Delcroix, T., and O. Lenormand, ENSO signals in the vicinity of New Caledonia, South Western Pacific, Oceanol. Acta, 20(3), 481-491, 1997.

de Villiers, S., G. T. Shen, and B. K. Nelson, The
$\mathrm{Sr} / \mathrm{Ca}$-temperature relationship in coralline aragonite: Influence of variability in $(\mathrm{Sr} / \mathrm{Ca})$ seawater and skeletal growth parameters, Geochim. Cosmochim. Acta, 58, 197-208, 1994.

de Villiers, S., M. Greaves, and H. Elderfield, An intensity ratio calibration method for the accurate determination of $\mathrm{Mg} / \mathrm{Ca}$ and $\mathrm{Sr} / \mathrm{Ca}$ of marine carbonates by ICP-AES, Geochem. Geophys. Geosyst., 3, 1001, doi:10.1029/ 2001GC000169, 2002.

Eisenhauer, A., K. Wyrwoll, L. Collins, Z. Zhu, G. Heiss, and B. Hansen, Sr/Ca- and U/Cathermometry of modern and fossil coral from the Abrolhos Islands and the Ningaloo Reef, Western Australia, Eos Trans. $A G U, 80(46)$, Fall Meet. Suppl., Abstract OS52A-18, 1999.

Fallon, S. J., M. T. McCulloch, R. van Woesik, and D. J. Sinclair, Corals at their latitudinal limits: Laser ablation trace element systematics in Porites from Shirigai Bay, Japan, Earth Planet. Sci. Lett., 172, 221-238, 1999.

Gagan, M. K., L. K. Ayliffe, D. Hopley, J. A. Cali, G. E. Mortimer, J. Chappell, M. T. McCulloch, and M. J. Head, Temperature and surface-ocean water balance of the midHolocene tropical Western Pacific, Science, 279, 1014-1017, 1998.

Gagan, M. K., L. K. Ayliffe, J. W. Beck, J. E. Cole, E. R. M. Druffel, R. B. Dunbar, and D. P. Schrag, New views of tropical paleoclimate from corals, Quat. Sci. Rev., 19, 167-182, 2000.

Hart, S. R., and A. L. Cohen, An ion probe study of annual cycles of $\mathrm{Sr} / \mathrm{Ca}$ and other trace elements in corals, Geochim. Cosmochim. Acta, 60, 3075-3084, 1996.

Lea, D. W., and E. A. Boyle, Determination of carbonate-bound barium in foraminifera and corals by isotope-dilution plasma-mass spectrometry, Chem. Geol., 103, 73-84, 1993.

Lea, D. W., and P. A. Martin, A rapid mass spectrometric method for the simultaneous analysis of barium, cadmium, and strontium in foraminifera shells, Geochim. Cosmochim. Acta, 60, 3143-3149, 1996

Lea, D. W., E. A. Boyle, and G. T. Shen, Coralline barium records temporal variability in equatorial Pacific upwelling, Nature, 340 , 373-376, 1989.

LeCornec, F., and T. Corrège, Determination of uranium to calcium and strontium to calcium ratios in corals by inductively coupled plasma mass spectrometry, J. Anal. At. Spectrom., 12, 969-973, 1997.

Linsley, B. K., R. G. Messier, and R. B. Dunbar, Assessing between-colony oxygen isotope variability in the coal Porites lobata at Clipperton Atoll, Coral Reefs, 18, 13-27, 1999.

Linsley, B. K., G. M. Wellington, and D. P. Schrag, Decadal sea surface temperature variability in the sub-tropical South Pacific (1726 to 1997 A.D.), Science, 290, 1145-1148, 2000.

Martin, P. A., D. W. Lea, T. A. Mashiotta, T. Papenfuss, and M. Sarthein, Variation of foraminiferal $\mathrm{Sr} / \mathrm{Ca}$ over Quaternary glacialinterglacial cycles: Evidence for changes in mean ocean Sr/Ca?, Geochem. Geophys. Geosys., 1, Paper number 1999GC000006, 1999.

McCulloch, M. T., M. K. Gagan, G. E. Mortimer, A. R. Chivas, and P. J. Isdale, A high-resolution $\mathrm{Sr} / \mathrm{Ca}$ and $\delta^{18} \mathrm{O}$ coral record from the Great Barrier Reef, Australia, and the 19821983 El Nino, Geochim. Cosmochim. Acta, 58, 2747-2754, 1994.

Min, G. R., R. L. Edwards, F. W. Taylor, C. D. Gallup, and J. W. Beck, Annual cycles of U/Ca in coral skeletons and U/Ca thermometry, Geochim. Cosmochim. Acta, 59, 2025-2042, 1995.

Mitsuguchi, T., E. Matsumoto, O. Abe, T. Uchi$\mathrm{da}$, and $\mathrm{P}$. J. Isdale, $\mathrm{Mg} / \mathrm{Ca}$ thermometry in coral skeletons, Science, 274, 961-963, 1996.

Oomori, T., K. Kaneshima, Y. Nakamura, and Y. Kitano, Seasonal variation of minor elements in coral skeletons, Galaxea, 1, 77-86, 1983.

Parker, D. E., M. M. Jackson, and E. B. Horton, The 1961-1990 GISST2.2 sea surface temperature and sea ice climatology, Clim. Res. Tech. Note 63 (CRTN63), Hadley Cent. for Clim. Predict. and Res., UK Met. Office, Bracknell, Berkshire, UK, 1995.

Pingitore, N. E., Y. Rangel, and A. Kwarting, Barium variations in Acropora palmata and Montastrea annularis, Coral Reefs, 8, 3136, 1989.

Quinn, T. M., and D. E. Sampson, Rapid and precise generation of multicentury coral-based climate records by HR-ICPMS, Eos Trans. $A G U, 79(45)$, Fall Meet. Suppl., 1998. 
Quinn, T. M., F. W. Taylor, T. J. Crowley, and S. M. Link, Evaluation of sampling resolution in coral stable isotope records: A case study using records from New Caledonia and Tarawa, Paleoceanography, 11, 529-542, 1996.

Quinn, T. M., F. W. Taylor, T. J. Crowley, C. Henin, P. Joannot, and Y. Join, A multicentury coral stable isotope record from a New Caledonia coral: Interannual and decadal sea surface temperature variability in the southwest Pacific since 1657 A.D., Paleoceanography, 13, 412-426, 1998.

Reeder, R. J., M. Nugent, G. M. Lamble, C. D. Tait, and D. E. Morris, Uranyl incorporation into calcite and aragonite: XAFS and luminescence studies, Environ. Sci. Technol., 34, 638644, 2000.

Ropelewski, C. F., and M. S. Halpert, Global and regional scale precipitation patterns associated with the El Nino/Southern Oscillation, Mon. Weather Rev., 115, 1606-1626, 1987.

Rosenthal, Y., M. P. Field, and R. M. Sherrell, Precise determination of element/Ca ratios in calcareous samples using sector field inductively coupled plasma mass spectrometry, Anal. Chem., 71, 3248-3253, 1999.

Schrag, D. P., Rapid analysis of high-precision
$\mathrm{Sr} / \mathrm{Ca}$ ratios in corals and other marine carbonates, Paleoceanography, 14, 97-102, 1999.

Shen, C.-C., T. Lee, C.-Y. Chen, C.-H. Wang, C.-F. Dai, and L.-A. Li, The calibration of $\mathrm{D}[\mathrm{Sr} / \mathrm{Ca}]$ versus sea surface temperature relationship for Porites corals, Geochim. Cosmichim. Acta, 60, 3849-3858, 1996.

Shen, G. T., and R. B. Dunbar, Environmental controls on uranium in reef corals, Geochim Cosmichim. Acta, 59, 2009-2024, 1995.

Shen, G. T., J. E. Cole, D. W. Lea, L. J. Linn, T. A. McConnaughey, and R. G. Fairbanks, Surface ocean variability at Galapagos from 1936-1982: Calibration of geochemical tracers in corals, Paleoceanography, 7, $563-$ 588, 1992.

Sinclair, D. J., L. P. Kinsley, and M. T. McColluch, High resolution analysis of trace elements in corals by laser ablation ICP-MS, Geochim. Cosmochim. Acta, 62, 1889-1901, 1998.

Smith, S. V., R. W. Buddemeier, R. C. Redalje, and J. E. Houck, Strontium-Calcium thermometry in coral skeletons, Science, 204, 404407, 1979.

Stoll, H. M., and D. P. Schrag, Effects of Quaternary sealevel cycles on strontium in seawater,
Geochim. Cosmochim. Acta, 62, 1107-1118, 1998.

Tudhope, A. W., D. W. Lea, G. H. Shimmield, C. P. Chilcott, and S. Head, Monsoon climate and Arabian Sea coastal upwelling recorded in massive corals from Southern Oman, Palaios, 11, 347-361, 1996.

Weber, J. N., Incorporation of strontium into reef skeletal carbonate, Geochim. Cosmochim. Acta, 37, 2173-2190, 1973.

Wei, G., M. Sun, X. Li, and B. Nie, $\mathrm{Mg} / \mathrm{Ca}, \mathrm{Sr} /$ $\mathrm{Ca}$ and $\mathrm{U} / \mathrm{Ca}$ ratios of a Porites coral from Sanya Bay, Hainan Island, South China Sea and their relationships to sea surface temperature, Palaeogeog. Palaeoclim. Palaeoecol., $162,59-74,2000$

T. M. Quinn, College of Marine Science, University of South Florida, 140 Seventh Ave., MSL 119, St. Petersburg, FL 33701, USA. (quinn@seas.marine.usf.edu)

D. E. Sampson, Department of Earth Sciences, University of California at Santa Cruz, Santa Cruz, Santa Cruz, CA 95064, USA. (dsampson@ earthsci.ucsc.edu) 